\title{
Coevolution of a Persistent Plant Virus and Its Pepper Hosts
}

\author{
Maliheh Safari, ${ }^{1,2}$ and Marilyn J. Roossinck ${ }^{1,2,+}$ \\ ${ }^{1}$ Department of Plant Pathology and Environmental Microbiology; and ${ }^{2}$ Center for Infectious Disease Dynamics, Pennsylvania \\ State University, State College, PA 16802, U.S.A.
}

Accepted 13 February 2018.

\begin{abstract}
There are many nonpathogenic viruses that are maintained in a persistent lifestyle in plants. Plant persistent viruses are widespread, replicating in their hosts for many generations. So far, Endornaviridae is the only family of plant persistent viruses with a single-stranded RNA genome, containing one large open reading frame. Bell pepper endornavirus (BPEV), Hot pepper endornavirus, Capsicum frutescens endornavirus 1 (CFEV 1) have been identified from peppers. Peppers are native to Central and South America and, as domesticated plants, human selection accelerated their evolution. We investigated the evolution of these endornaviruses in different peppers including Capsicum annuum, C. chacoense, C. chinense, C. frutescens, C. baccutum, and $C$. pubescens using two fragments from the viral helicase (Hel) and RNA dependent RNA polymerase (RdRp) domains. In addition, using single nucleotide polymorphisms, we analyzed the pepper host populations and phylogenies. The endornaviruses phylogeny was correlated with its Capsicum species host. In this study, BPEV was limited to $C$. annuum species, and the RdRp and Hel phylogenies identified two clades that correlated with the host pungency. No $C$. annuum infected with CFEV 1 was found in this study, but the CFEV 1 RdRp fragment was recovered from $C$. chinense, $C$. frutescens, $C$. baccutum, and $C$. pubescens. Hence, during pepper speciation, the ancestor of CFEV 1 may have evolved as a new endornavirus, BPEV, in C. annuum peppers.
\end{abstract}

There are many cytoplasmic RNA viruses reported, from plants, that persist for many generations through nearly $100 \%$ vertical transmission. These viruses are very poorly studied, even though they are found in many crops and are the most common viruses found in wild plants (Roossinck 2012, 2015). Generally, persistent plant viruses are reported with no effect on their host, although finding an isogenic virus-free plant to use for comparison is not always possible. However, in clover and in a model legume, Lotus japonicus, the coat protein gene of the partitivirus White clover cryptic virus 2 affects nodulation regulation (Nakatsukasa-Akune et al. 2005).

The viruses in the family Endornavirirdae are found in plants, fungi, oomycetes, and protists. The endornaviruses have

${ }^{\dagger}$ Corresponding author: Marilyn Roossinck; E-mail: mjr25@psu.edu

Funding: This work was supported by the Pennsylvania State University College of Agricultural Sciences.

*The $\boldsymbol{e}$-Xtra logo stands for "electronic extra" and indicates that two supplementary figures and five supplementary tables are published online.

(c) 2018 The American Phytopathological Society a single-stranded RNA genome of 9,800 to17,600 nts that contains a single open reading frame (ORF) encoding a large polyprotein (Fukuhara and Moriyama 2008). The virus is not encapsidated and, for this reason, the replicative intermediate double-stranded (ds)RNA is most often found in hosts, but the RNA dependent RNA polymerase (RdRp) indicates that the genome is single-stranded (Roossinck et al. 2011). Additional identified domains in the large polyprotein are methyltransferase (MTR), helicase (Hel), capsular polysaccharide synthase protein, and glycosyltransferase (GT) domains. All members of this family have a highly conserved RdRp at the $\mathrm{C}$ terminal end of the ORF, which is most similar to the RdRp of closteroviruses. The other domains are not conserved among all endornaviruses (Roossinck et al. 2011). A Hel domain is reported from most of the endornaviruses, but the origins of the Hel domains are clearly different in different viruses (Roossinck et al. 2011). Endornaviruses are found in many plants, including rice, wild rice, kidney bean, broad bean, barley, cucurbits, yerba mate, Malabar spinach, grapevine, avocado, and peppers (Coutts 2005; Debat et al. 2014; Espach et al. 2012; Moriyama et al. 1995; Okada et al. 2014; Pfeiffer 1998; Valverde and Gutierrez 2008; Villanueva et al. 2012; Wakarchuk and Hamilton 1990; Zabalgogeazcoa and Gildow 1992). All the plants with endornaviruses are reported as healthy and normal, although in Vicia faba male sterility is associated with the presence of Vicia faba endornavirus (Pfeiffer 1998).

Oryza sativa endornavirus is found in all japonica cultivars but not in indica cultivars of rice (Horiuchi et al. 2003). Oryza rufipogon is the ancestor of domesticated japonica rice and has a related persistent virus, Oryza rufipogon endornavirus. Around 10,000 years ago, the hosts of these two viruses diverged during the cultivation of rice (Molina et al. 2011). Assuming the virus was already present at the time of domestication, these viruses have diverged by only about $24 \%$ over 10,000 years. This is a surprisingly slow evolution rate for RNA viruses with previously reported rates of $10^{-3}$ to $10^{-4}$ substitutions per site per year (Roossinck 1997; Roossinck and Ali 2007; Pagán and Holmes 2010).

A large dsRNA was first reported from tissue extracts of healthy bell peppers (Capsicum annuum) (Valverde et al. 1990), and in 2007, the partial sequence analysis revealed that the dsRNA is the genome of an endornavirus, now named Bell pepper endornavirus (BPEV) (Valverde and Gutierrez 2007). The vertical transmission of BPEV is very high (close to $100 \%$ ) when both parents are virus-infected (Okada et al. 2011). The single ORF of BPEV starts at nucleotide 225 and ends at nucleotide 14,670, encoding a 4,815-amino acid polyprotein with an estimated molecular mass of $545 \mathrm{kDa}$ (Okada et al. 2011). BPEV contains four identified domains: MTR, Hel, GT, and RdRp (Supplementary Fig. S1) (Roossinck et al. 2011). It is presumed that the large protein is proteolytically cleaved into functional domains, although a protease has not been identified. Analysis of pepper viromes revealed 
coinfection with BPEV and several acute viruses in Pusa Jwala and Taiwan 2 pepper cultivars (Jo et al. 2017).

In addition to BPEV, Hot pepper endornavirus (HPEV) was reported from a chili pepper (C. annuum), with $72 \%$ nucleotide identity to the BPEV Yolo Wonder isolate and containing all four identified domains of BEPV (Lim et al. 2015). An additional endornavirus, Capsicum frutescens endornavirus 1, was isolated from the tabasco cultivar of $C$. frutescens (R. Valverde personal communication).

Peppers are economically important crops of the Solanaceae family. A broad area along the Andes in South America including Peru, Ecuador, and Colombia is thought to be the origin of Capsicum spp. (Carrizo García et al. 2016). The genus apparently migrated from South America northward around 6 million years ago, resulting in the dispersal and speciation events. Bolivia and Peru are thought to be the centers of diversification and cultivation of peppers (Carrizo García et al. 2016). The Capsicum genus consists of approximately 35 species, of which $C$. annuum L., C. baccatum L., C. chinense Jacq., C. frutescens L., and C. pubescens (Ruiz \& Pavon) are domesticated species that now are grown all over the world (Carrizo García et al. 2013; Qin et al. 2014). Domesticated species of peppers are derived from three distinct genetic lineages. One lineage includes the members of a species complex, $C$. frutescens, $C$. annuum, and $C$. chinense, that were derived independently from wild progenitors, whereas $C$. pubescens and $C$. baccatum are each independent lineages (Eshbaugh 1993; Hill et al. 2013; Pickersgill 1997). The most common cultivated Capsicum species is $C$. annuum, which was domesticated in Mexico from chiltepin (C. annuum var. glabriusculum). Cultivated peppers are divided into two main groups of sweet and pungent peppers. Bell peppers are all sweet $C$. annuиm cultivars and are found in a variety of colors with blocky shaped fruits. Pungent peppers, often called chile peppers, refer to a large number of varieties with mild to extreme pungency and belong to $C$. annuum, $C$. frutescens, $C$. chinense, $C$. pubescens, and C. baccatum (Hulse-Kemp et al. 2016).

Based on the whole-genome sequencing data, domestication has led to an increase in the size of the pepper genome (Qin et al. 2014), but cultivation has resulted in a significant decline in genetic variation. Significant decreases in wild chiltepin populations have occurred over the last few thousand years (González-Jara et al. 2011). Until very recently the origins, relationships, and domestication of peppers were unclear, but markers are now available that allow detailed phylogenetic trees of peppers to be constructed (Hill et al. 2013; Kraft et al. 2014; Qin et al. 2014). For polymorphism detection and expression analysis in Capsicum spp., a pepper GeneChipH array was developed, with 40 different $C$. annuum lines and cultivated $C$. frutescens, $C$. chinense and C. pubescens tested, resulting in detection of 33,401 single position polymorphism markers. The diversity in nonpungent peppers was reduced three-fold compared with pungent lines (Hill et al. 2013).

Endornaviruses are found in a number of both sweet and pungent pepper cultivars. In this study, we investigated the origin, natural history, and evolution of two persistent viruses, BPEV and Capsicum frutescens endornavirus 1 (CFEV 1), in different pepper cultivars. We used a single nucleotide polymorphism (SNP)-based method, Kompetitive Allele Specific PCR (KASP) assay (Ashrafi et al. 2012; He et al. 2014; HulseKemp et al. 2016), to assess the evolutionary history of the hosts of these two endornaviruses.

\section{RESULTS}

\section{Screening Capsicum spp. for the presence of endornaviruses.}

After dsRNA extraction from peppers, the presence of BPEV or CFEV 1 was confirmed by reverse transcription-polymerase chain reaction (RT-PCR), using specific primers for each virus. The RT-PCR products (BPEV_RdRp, 1,240 bp; BPEV_Hel, 1,162 bp; CFEV 1_RdRp, 1,101 bp; CFEV 1_Hel, 1,016 bp) were analyzed by Sanger sequencing to obtain the consensus sequence for each virus. We detected BPEV in 10 of 33 different $C$. annuum pepper cultivars, including Marengo, Chocolate, Greek Pepperoncini, Hungarian YW, Peter, Joe's Long Cayenne, Padron Hot, Jimmy Nardello's, Neapolitan, and Feher Ozon Paprika (Tables 1 and 2). BPEV has been detected mainly in the samples that were from the United States, except for Chocolate pepper from Guatemala (Fig. 1). Most of the United States virus-positive samples were received from the Hudson Valley and Victory Seeds companies, and we do not have any precise information about their origins and breeding history. Although we considered them as United States samples, the probable origins of some of them are different, specifically, Feher Ozon Paprika and Hungarian YW are probably from Hungary; Greek Pepperoncini is probably from Greece; Padron is likely from Spain; and Neapolitan is likely from Italy.

We did not detect CFEV 1 in any C. annuum peppers, but 24 different peppers in diverse Capsicum species were infected with this virus; 13 of $16 \mathrm{C}$. baccatum, five of $11 \mathrm{C}$. chinense, five of $18 C$. frutesces, and one of eight $C$. baccatum were positive for CFEV 1 (Tables 1 and 2). Origins of the seeds for the CPEV1-positive plants are shown in Figure 1.

Using CFEV 1_RdRp primers an 875-bp fragment was amplified from dsRNA extracted from the Ember cultivar (C. annuum), which had $94 \%$ nucleotide identity to the Cs isolate of HPEV reported from South Korea (Lim et al. 2015). We did not detect BPEV or CFEV 1 in eight accessions of chiltepin (C. annuum var. glabriusculum) or two accessions of $C$. chacoense in our pepper collection.

\section{Deep sequencing of the Marengo isolate of BPEV.}

Using Illumina sequencing, we obtained a contig of $14,290 \mathrm{bp}$ from Marengo peppers, corresponding to nucleotides 223 to 14,512 of BPEV, that differed from the strain amplified using BPEV-specific primers (strain Marengo1). The RdRp and Hel fragments of this isolate (Marengo2) had 90 and $88 \%$ nucleotide identity to BPEV Marengo1, respectively. The Marengo2 strain had $99 \%$ nucleotide identity to the Maor isolate, while both RdRp and Hel fragments of BPEV Marengol showed highest nucleotide identity (99 and 97\%, respectively) to the Yolo Wonder isolate.

\section{Virus phylogenies.}

In addition to the $10 \mathrm{BPEV}$ isolates detected in this study, the nucleotide sequences of 12 full-length sequences of BPEV available in GenBank (Supplementary Table S3) were included in the phylogenetic analysis. Pairwise identity was 88 to $100 \%$ among BPEV_RdRp nucleotide sequences and 87 to $100 \%$ among BPEV_Hel sequences. Phylogenetic analysis using the nucleotide sequence of both fragments resulted in two main clades (Fig. 2). In the BPEV_RdRp phylogeny clade 1 (Fig. 2A), viruses isolated from different pepper varieties (Marengo1, Greek Pepperoncini Hungarian YW, Peter, Joe's Long Cayenne, Padron Hot, Jimmy Nardello's, and Neapolitan) are grouped together with Yolo Wonder, Pusa Jwala, and Taiwan 2 isolates (accession numbers are provided in Supplementary Table S1). All isolates in clade 1 are from pungent peppers, except Marengo1 and Yolo Wonder. BPEV isolates from Chocolate, Feher Ozon Paprika, and the Marengo2 strain are grouped in clade 2, which included all sweet pepper isolates (lj, Phenol, Santa Fe, Kyosuzu, IS, Maor, and Healy) except Chocolate and Santa Fe isolates, which are pungent peppers (Gutiérrez et al. 2017). In the BPEV_Hel phylogeny, the same pattern of two clades was observed; clade 1 contained isolates from pungent peppers and 
clade 2 had the sweet pepper isolates (except Chocolate and Santa Fe). However, the BPEV_Hel fragment from Yolo Wonder grouped with the other sweet pepper isolates (Fig. 2B, clade 2), which indicates recombination in this virus, as was previously suggested in another study (Jo et al. 2016).

A Bayesian phylogenetic tree was constructed using nucleotide sequences of pepper endornavirus RdRp regions (BPEV, CFEV 1, and HPEV isolates), with Phaseolus vulgaris endornavirus 2 as an outgroup (Fig. 3). This tree contains two main clades. Two HPEV isolates (Cs and Ember) were grouped together with BPEV isolates in clade $\mathrm{A}$, all of which are isolated from $C$. annuum species. The second clade contained the CFEV 1 isolates. CFEV 1 from Aribibi Gusano pepper (C. frutescens) was distinct from the rest of isolates and, with a posterior probability of 1 , may be ancestral to the rest of the CFEV 1 isolates. CFEV 1, isolated from two Habaneros, Royal Gold, and 30040 peppers (all from $C$. chinense), were grouped with three Tabasco peppers (C. frutescens) and were placed in clade $\mathrm{CF}$. The BCP clade included isolates mostly from C. baccatum, with the exceptions of Ecu (from $C$. pubescens) and Chile Blanco and Lemon Drop (C. chinense) (Fig. 3). The CFEV 1 isolates from Aribibi Gusano and Habanero Red showed 83 to $85 \%$ nucleotide identity to other CFEV 1 isolates, while there was 94 to $100 \%$ nucleotide identity among isolates in the CF clade and 90 to $100 \%$ nucleotide identity among isolates in the BCP clade.

Using specific primers, the CFEV 1_Hel fragment was amplified only from Tabasco (Tabasco L-64 and Greenleaf Tabasco, both $C$. frutescens) and 30040 (C. chinense) peppers. Also, in the endornaviruses Hel phylogeny all $C$. annum isolates (BPEV and HPEV isolates) grouped together and CFEV 1 isolates from $C$. frutescens and $C$. chinense grouped in a second clade (Supplementary Fig. S2).

Pepper phylogenies and population structure.

To examine the population structure in the Capsicum spp. using SNP data from the KASP analysis, Bayesian clustering was implemented in STRUCTURE software. The distribution of the 38 Capsicum spp. into three distinct clusters is shown in Figure 4A (cluster 1 in red, cluster 2 in green =, and cluster 3 in blue). In cluster 1, Marengo, Jimmy Nardello's, Padron Hot, Ember, Greek Pepperoncini, Hungarian YW, Long Red Cayenne, Feher Ozon Paprika, Joe's Long Cayenne, Chiltepin102, and Diente De Perro are clustered together. Chiltepin54, Serrano Hot, Jalapeño, Chiltepin53, Peter, Chocolate, and Jalapeño

Table 2. Number of positive samples in each Capsicum species

\begin{tabular}{lccc}
\hline Species & No. of lines $^{\mathbf{a}}$ & BPEV $^{\mathbf{b}}$ & CFEV 1 $^{\mathbf{c}}$ \\
\hline C. annuum var. annuum & 33 & 10 & 0 \\
C. annuum var. glabriusculum & 8 & 0 & 0 \\
C. baccatum & 16 & 0 & 13 \\
C. frutescens & 18 & 0 & 5 \\
C. chinense & 11 & 0 & 5 \\
C. pubescens & 8 & 0 & 1 \\
C. chacoense & 2 & 0 & 0 \\
\hline
\end{tabular}

${ }^{a}$ Number of lines tested for Bell pepper endornavirus (BPEV) and Capsicum frutescens endornavirus 1 (CFEV 1).

b Number of lines positive for BPEV.

c Number of lines positive for CFEV 1.

Table 1. Peppers with a detected endornavirus

\begin{tabular}{|c|c|c|c|c|}
\hline Names in the tree ${ }^{a}$ & Type & Species & $\mathbf{P I}^{\mathbf{b}}$ & Virus \\
\hline BPEV_Marengo & Sweet & Capsicum anпиит var. аппиит & - & BPEV \\
\hline BPEV_Jimmy Nardello’s & Pungent & C. апnиит var. аппиит & - & BPEV \\
\hline BPEV_Feher Ozon Paprika & Sweet & C. аппиит var. аппиит & - & BPEV \\
\hline BPEV_Joe's long cayenne & Pungent & C. annuиm var. апnиит & - & BPEV \\
\hline BPEV_Greek Pepperoncini & Pungent & C. апnиит var. аппиит & - & BPEV \\
\hline BPEV_Hungarian YW & Pungent & C. апnиит var. аппиит & - & BPEV \\
\hline BPEV_Padron Hot & Pungent & C. аппиит var. аппиит & - & BPEV \\
\hline BPEV_Neapolitan & Pungent & C. апnиит var. аппиит & - & BPEV \\
\hline BPEV_Peter & Pungent & C. аппиит var. аппиит & - & BPEV \\
\hline BPEV_Chocolate & Sweet & C. аппиит var. аппиит & PI 666471 & BPEV \\
\hline CFEV 1_Habanero Red & Pungent & C. chinense & - & CFEV 1 \\
\hline CFEV 1_Chile Blanco & Pungent & C. chinense & PI 574545 & CFEV 1 \\
\hline CFEV 1_30040 & Pungent & C. chinense & PI 159236 & CFEV 1 \\
\hline CFEV 1_Royal Gold & Pungent & C. chinense & PI 315023 & CFEV 1 \\
\hline CFEV 1_Lemon Drop & Pungent & C. chinense & PI 315024 & CFEV 1 \\
\hline CFEV 1_Aribibi Gusano & Pungent & C. frutescens & PI 573337 & CFEV 1 \\
\hline CFEV 1_Greenleaf Tabasco Al & Pungent & C. frutescens & PI 634826 & CFEV 1 \\
\hline CFEV 1_Tabasco L-167 & Pungent & C. frutescens & PI 640909 & CFEV 1 \\
\hline CFEV 1_Habanero & Pungent & C. chinense & - & CFEV 1 \\
\hline CFEV 1_Ecu & Pungent & C. pubescens & PI 585262 & CFEV 1 \\
\hline CFEV 1_Lemon Drop Hot & Pungent & C. baccatum & - & CFEV 1 \\
\hline CFEV 1_WTS-14 & Pungent & C. baccatum var. pendulum & PI 595905 & CFEV 1 \\
\hline CFEV 1_WWMC126 & Pungent & C. baccatum var. pendulum & PI 632927 & CFEV 1 \\
\hline CFEV 1_WW141 & Pungent & C. baccatum var. pendulum & PI 633756 & CFEV 1 \\
\hline CFEV 1_MC145 & Pungent & C. baccatum var. pendulum & PI 633757 & CFEV 1 \\
\hline CFEV 1_MC147 & Pungent & C. baccatum var. pendulum & PI 633758 & CFEV 1 \\
\hline CFEV 1_Malagueta & Pungent & C. baccatum var. pendulum & PI 260543 & CFEV 1 \\
\hline CFEV 1_Valentine & Pungent & C. baccatum var. pendulum & PI 260549 & CFEV 1 \\
\hline CFEV 1_Omnicolor & Pungent & C. baccatum var. pendulum & PI 260590 & CFEV 1 \\
\hline CFEV 1_82 & Pungent & C. baccatum var. pendulum & PI 337522 & CFEV 1 \\
\hline CFEV 1_BGH 4215 & Pungent & C. baccatum var. pendulum & PI 441589 & CFEV 1 \\
\hline CFEV 1_470 & Pungent & C. baccatum var. baccatum & PI 215699 & CFEV 1 \\
\hline CFEV 1_No 1553 & Pungent & C. baccatum var. baccatum & PI 238061 & CFEV 1 \\
\hline HPEV_Ember & Pungent & C. аппиит var. аппиит & PI 273426 & HPEV \\
\hline
\end{tabular}

${ }^{a}$ Names appear with virus name followed by cultivar name or plant designation. BPEV = Bell pepper endornavirus; CFEV $1=$ Capsicum frutescens endornavirus 1.

b Plant Introduction number. 
Criollo are grouped together in cluster 2. Cluster 3 includes Chiltepin30, Chile Blanco, WWMC 126, Ecu, Lemon Drop Hot, Aribibi Gusano, 30040, Omnicolor, Habanero Red, Valentine, Royal Gold, WW141, Malagueta, No1553, 470, BGH4215, Lemon Drop, Tabasco L167, Greenleaf Tabasco Al, and MC145.
Population structure analysis revealed admixture in Joe's Long Cayenne and Diente De Perro from cluster 1 with peppers in cluster 2. Peter, Chocolate, and Jalapeño Criollo peppers have admixtures with genotypes in cluster 1. Peppers in clusters 1 and 2 belong to $C$. annuum, except Diente De Perro, which

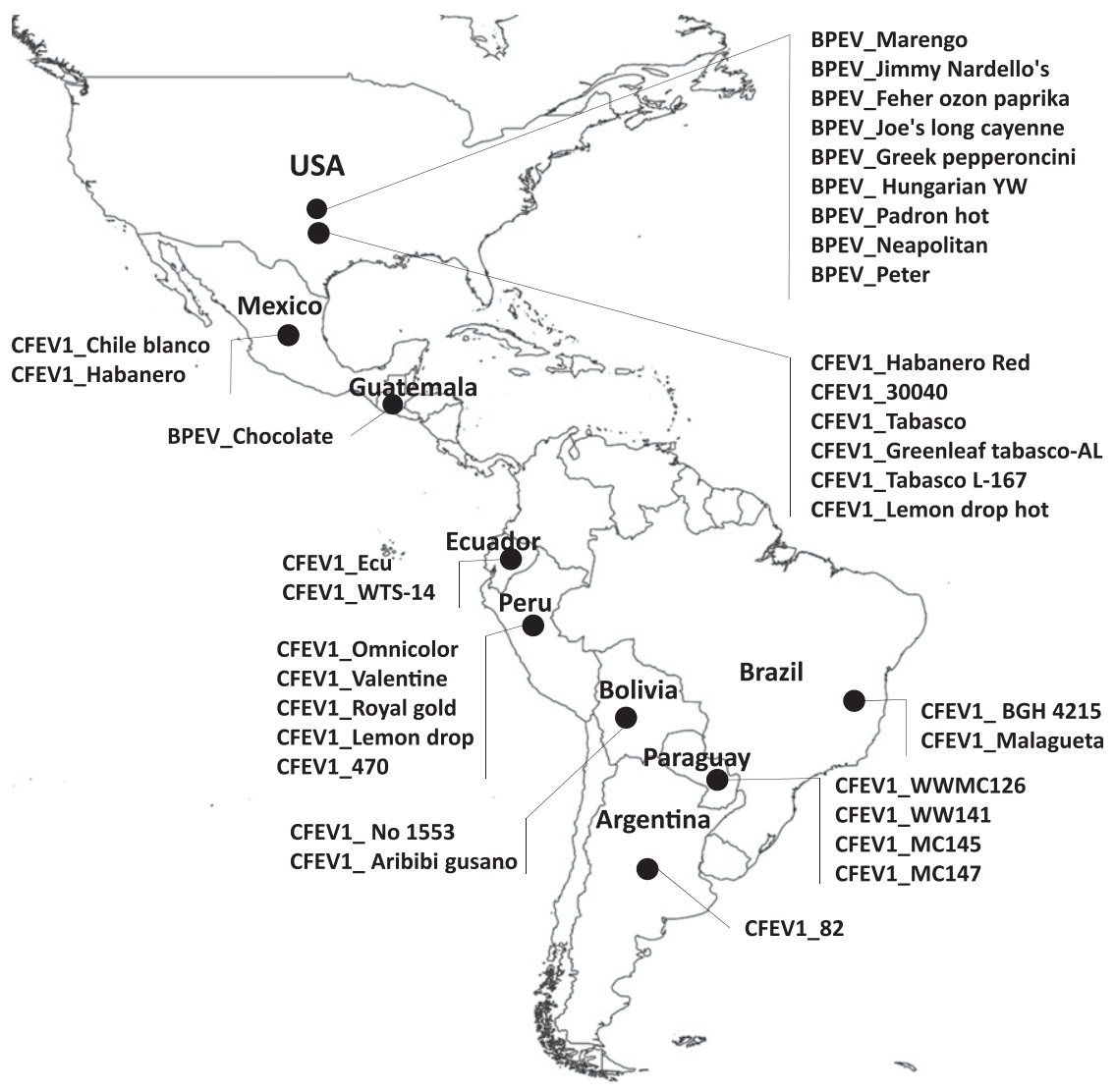

Fig. 1. The distribution map of detected endornaviruses. Bell pepper endornavirus (BPEV) and Capsicum frutescens endornavirus 1 (CFEV 1). Location indicates the country from which the seeds were obtained, but the probable origins of the seeds are, Marengo, United States; Jimmy Nardello, United States; Feher Ozon Paprika, Hungary; Joe's long cayenne, United States; Greek pepperoncini, Greece; Hungarian YW, Hungary; Padron hot, Spain; Neapolitan, Italy; and Peter, United States.

A

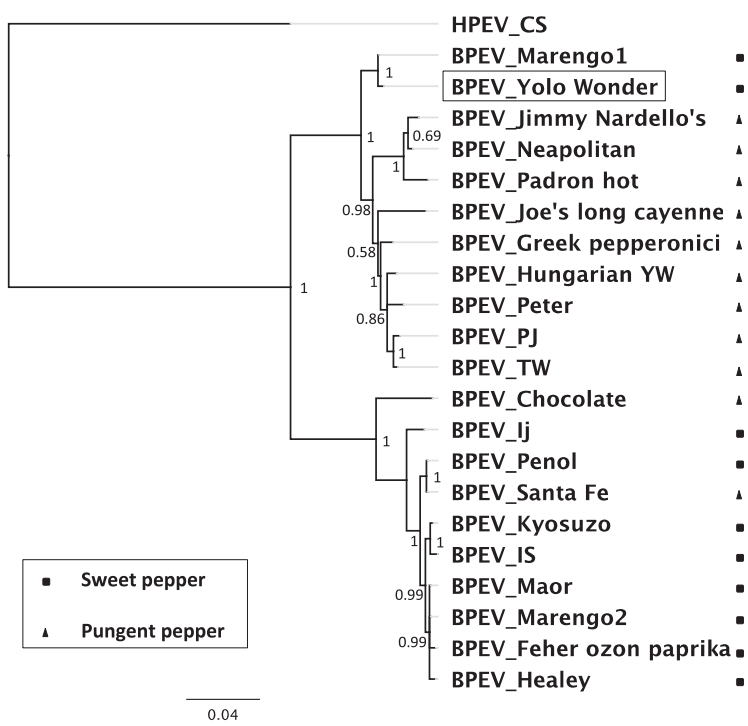

B

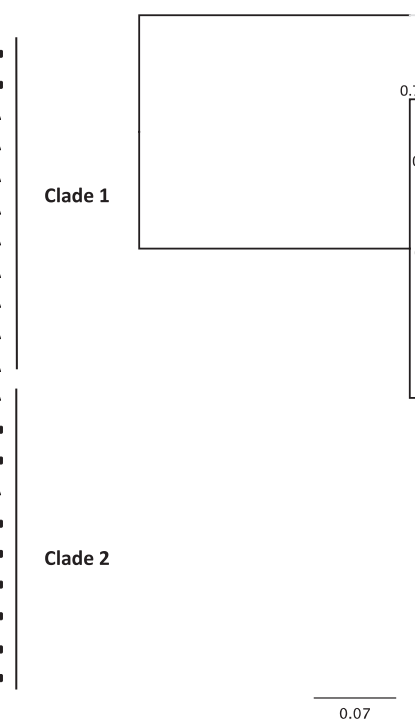

HPEV_CS

BPEV_Marengo 1

BPEV_Joe's long cayenne: BPEV_Padron Hot

BPEV_Jimmy Nardello's BPEV_Neapolitan

BPEV_Greek pepperonici $\quad$ Clade 1 BPEV_Hungarian YW

BPEV_Peter

BPEV_PJ

BPEV_TW

\begin{tabular}{|lll|}
\hline & BPEV_Yolo Wonder \\
\hline 0.75 & BPEV_Chocolate
\end{tabular}

BPEV_Lj

BPEV_Peno

BPEV_Santa Fe

BPEV_Feher Ozon Paprika.

BPEV_Kyosuzo

0.79 BPEV_IS

BPEV_Maor

BPEV_Marengo 2

BPEV_Healey

Fig. 2. Relationships of Bell pepper endornavirus (BPEV) isolates. Bayesian analysis of the relationships among aligned nucleotide sequences of BPEV isolated from different peppers. Trees were generated by MrBayes in Geneious 10.0.9, using the best fit model (HKY + I). Posterior probabilities are shown on nodes. Hot pepper endornavirus (HPEV) was used as an outgroup. A, BPEV_RdRp; B, BPEV_Hel. 
was identified as $C$. frutescens, based on its morphological characteristic, but this result indicates that it belongs to C. annuum. Pepper lines in cluster 3 corresponded to peppers positive for CFEV 1, except Chiltepin30. Chiltepin30 and Chile Blanco showed admixed genomes $(<20 \%)$ with cluster 2 . Based on our SNP data, few variations were detected in SNP data from non-annuиm species and they were grouped together in cluster 3.

Ecu pepper ( $C$. pubescens) was used as an outgroup for the Baysian phylogenetic tree for the 38 pepper samples. This tree is in general agreement with the previous population clustering and the endornaviruses phylogenies (Fig. 4B). The clade highlighted in red includes hosts of clade 1 from the BPEV phylogeny, including Feher Ozon Paprika. However, Peter and Chocolate peppers, both positive for BPEV, are in the green-highlighted part of the pepper phylogenies. All pepper lines in the red- and greenhighlighted groups belonged to $C$. annuum and are clustered with Chile Blanco (C. chinense) and Chiltepin30; Chiltepin102 is the probable ancestor. The final grouping includes the various nonannuum species of peppers, in which all of the CFEV 1-positive plants are placed and in which there is less than $2 \%$ variation in the SNP data.

\section{DISCUSSION}

In this study, we detected BPEV only in C. annuum and in none of the other Capsicum species. Previously, BPEV was reported, from several domesticated Capsicum species (C. annuиm,
C. frutescens, C. chinense, and C. baccatum), by using degenerate primers to amplify a 381-nt fragment of the RdRp (Okada et al. 2011). However, with a more comprehensive analysis of the $\mathrm{RdRp}$, we found that all the non-annuum isolates were CFEV 1. The limitation of BPEV to $C$. annuum is surprising, because this virus can be transmitted by cross-pollination (Valverde and Gutierrez 2007) and hybrids of C. annuum with C. baccatum and C.chinense are fertile.

BPEV has been reported from the United States, Colombia, Canada, China, Japan, Taiwan, India, South Korea, and Israel (Jo et al. 2016; Gutiérrez et al. 2017; Lim et al. 2015; Okada et al. 2011; Valverde and Gutierrez 2007). In this study, all cultivars were from the Americas, and BPEV was found in the United States samples and a Chocolate pepper from Guatemala. Hence, BPEV has been distributed all over the world by pepper dispersal. In structure analysis and pepper phylogenies (Fig. 4), Chocolate pepper was nested within chiltepins, the ancestor of $C$. annuum peppers. While BPEV has not been identified in any chiltepin in this study or previous studies (Okada et al. 2011)), Chocolate pepper may be the origin of introduction of this virus to $C$. annuum.

The admixture observed within $C$. annum samples (Fig. 4A) revealed the exchange of genetic material between cultivars by breeding and natural cross-pollination. Among four different chiltepins (C. annuum var. glabriusculum) used in this analysis, Chiltepin102, included in cluster 1 , revealed an admixture (approximately 25\%) with cluster 3, Chiltepin53 and Chiltepin54 clustered with peppers in cluster 2 and Chiltepin 30 in cluster 3

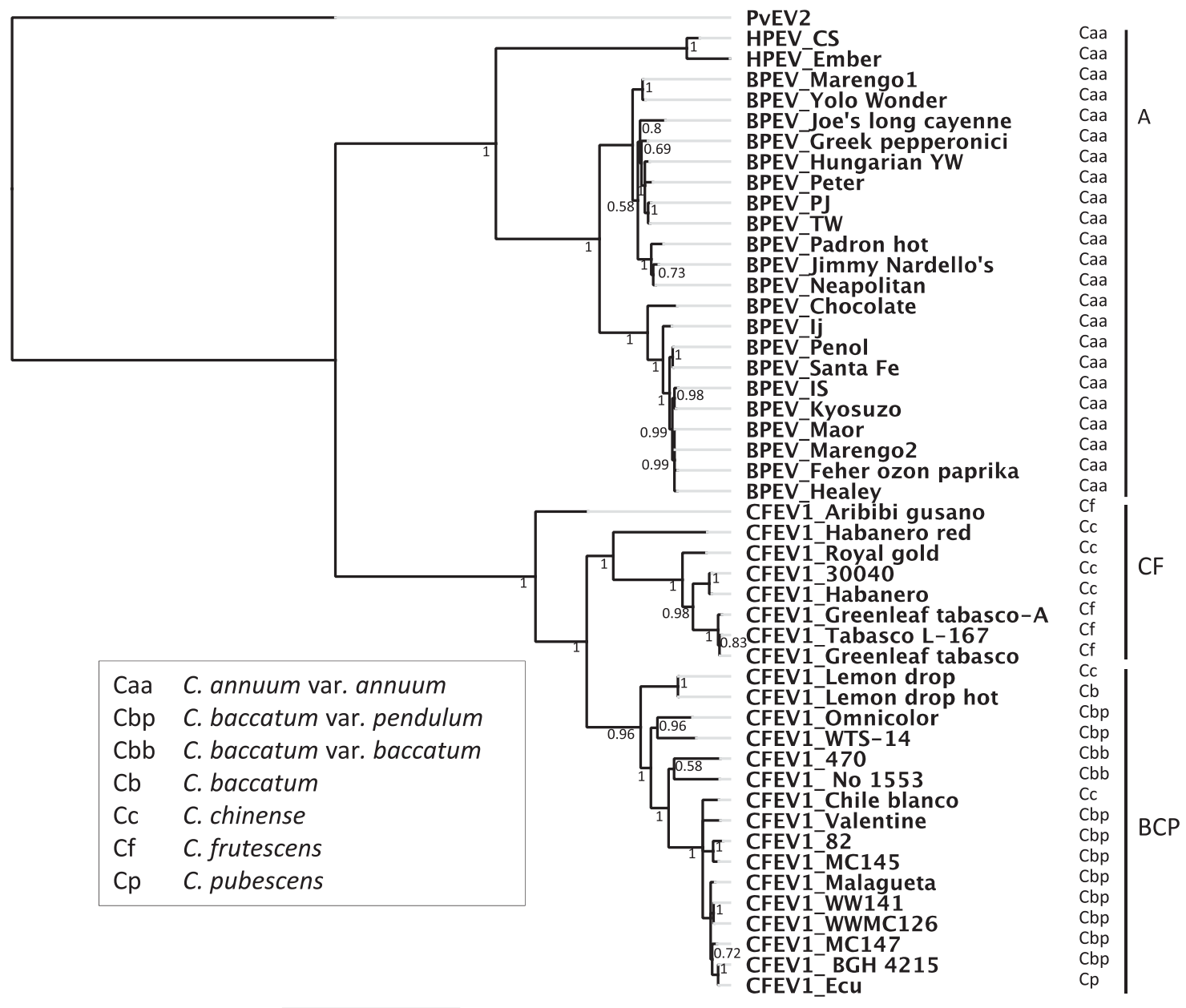

0.2

Fig. 3. Relationships among endornaviruses. Bayesian analysis of the relationships among aligned nucleotide sequences of the RNA dependent RNA polymerase fragment of pepper endornaviruses. Phaseolus vulgaris endornavirus 2 (PvEV 2) was used as an outgroup. Trees were generated by MrBayes in Geneious 10.0.9, using GTR + I + G. Posterior probabilities are shown on nodes. 
with an admixed genome with cluster 1 . This result is consistent with a previous study that used microsatellite markers for pepper (Nicolai et al. 2013).

Phylogenetic analysis of nucleotide sequences of BPEV RdRp and Hel fragments revealed two main clades in both domains, corresponding to the pepper pungency (Fig. 2). Clade 1 included BPEV isolates mainly from pungent pepper and clade 2 from sweet peppers. Two strains of BPEV in Marengo were separated in both BPEV phylogenies. Strain Marengo1 was nested between isolates from pungent peppers, and the Marengo2 strain was placed within sweet pepper isolates. The presence of different strains could result from cross-pollination between peppers, since persistent viruses are transmitted by pollen and ovum (Roossinck 2010). SNP profiles in the transcriptome data from a Maor pepper revealed more than one BPEV variant in this cultivar as well (Jo et al. 2016).

BPEV_Hel from Yolo Wonder showed evidence of recombination in this virus. A schematic diagram of BPEV_Hel alignment is shown in Figure 5A, with the color code based on the SNP similarity between different isolates. In Yolo Wonder, sequences were similar to clade 1 isolates until position 875 (H1, shown in purple), while after position 875 (H2, shown in green) sequences were similar to isolates in clade 2 . In the phylogenetic trees of the $\mathrm{H} 1$ and $\mathrm{H} 2$ fragments (Fig. 5B), the Yolo Wonder isolate is grouped within clade 1 in $\mathrm{H} 1$, with pungent pepper isolates, and in clade 2 in the $\mathrm{H} 2$ phylogeny, with sweet pepper isolates. In the $\mathrm{H} 1$ fragment, pairwise identity was 88 to $100 \%$, while identity was 80 to $100 \%$ in $\mathrm{H} 2$, so there is more variation in the second part $(\mathrm{H} 2)$ of the BPEV_Hel fragment. Except for three positions, all the substitutions are synonymous.

The phylogenetic tree of pepper endornaviruses was correlated with pepper species with few exceptions. Two HPEVs (Cs and Ember isolates) and all BPEV isolates were included in clade A, all from $C$. annuum species. The CFEV 1 isolates had two main clades, isolates in the $\mathrm{CF}$ clade were from

A

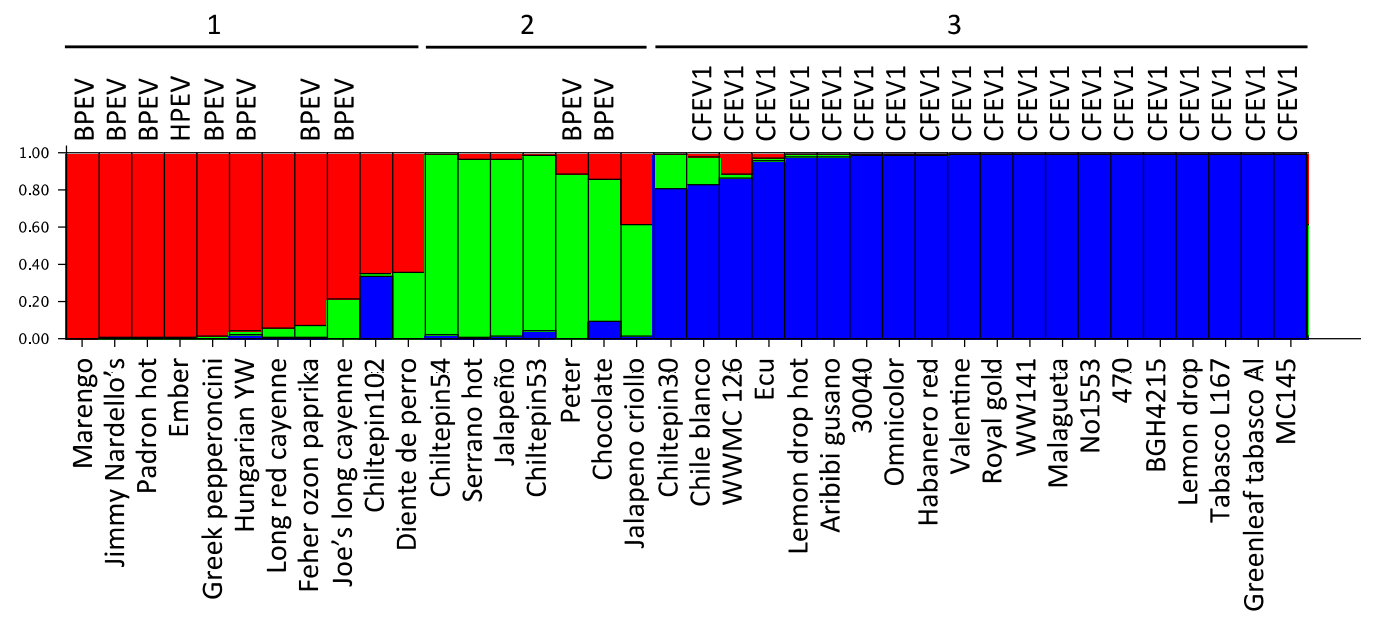

B

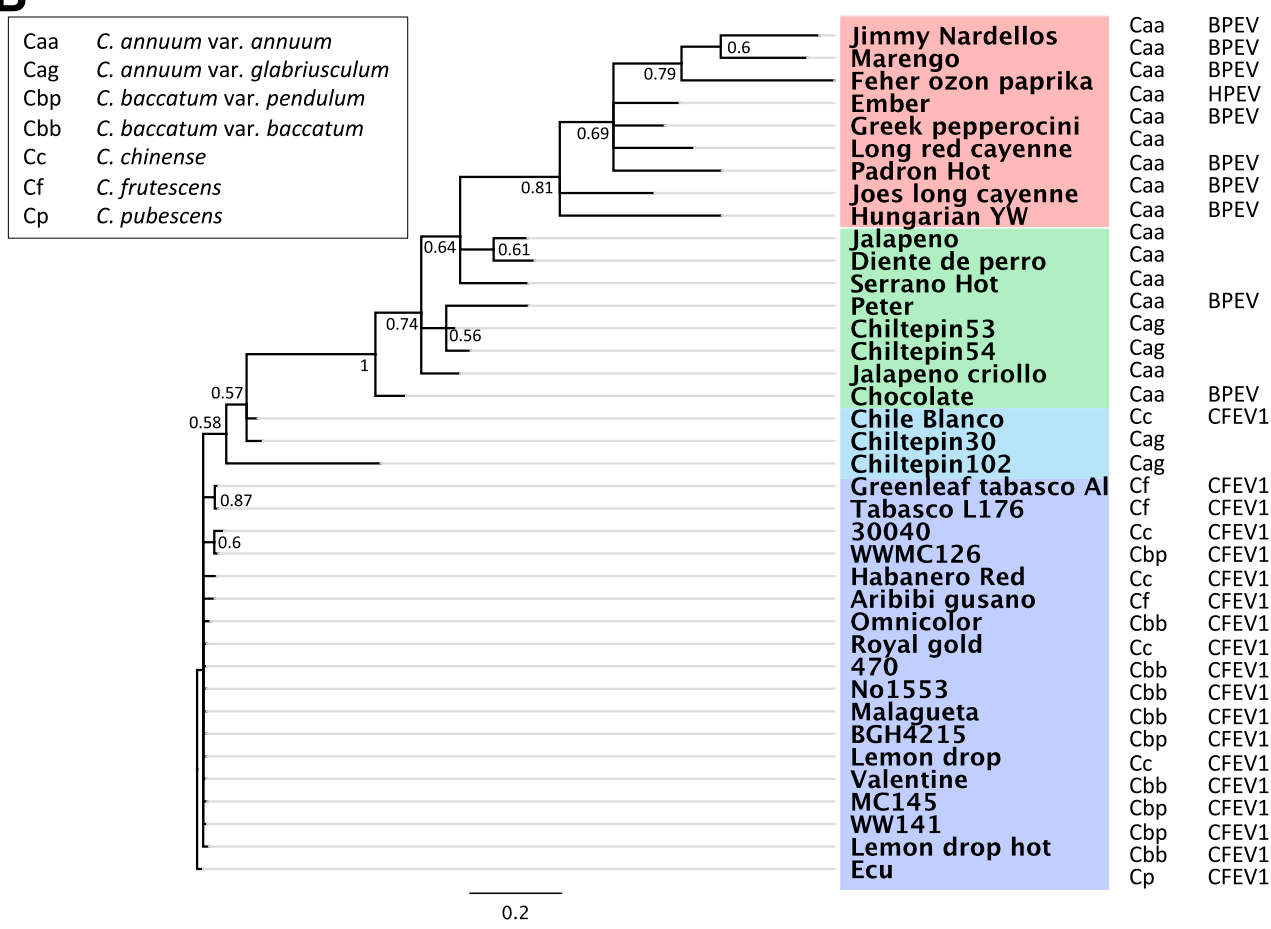

Fig. 4. Population structure of pepper hosts. A, Population structure analysis of single nucleotide polymorphism (SNP) data, using STRUCTURE software (2.3.4). The distribution of the 38 Capsicum spp. lines into three distinct clusters is shown in red (cluster 1), green (cluster 2), and blue (cluster 3). B, Bayesian analysis of the relationships among SNPs in different pepper lines. Ecu (from C. pubescens) was used as an outgroup. The tree was generated by MrBayes in Geneious 10.0.9, using GTR + I. Posterior probabilities are shown on nodes. 
C. chinense and C. frutescens and the BCP clade contained isolates mainly from $C$. baccatum peppers. Species classifications have been based on morphological traits (flowers, leaves, and fruits), which were defined by different people. So, in addition to genome introgression by interspecific crossing between compatible species, there also is a possibility of previous misclassification of species (Shirasawa et al. 2013).

In Figure 6, the BPEV_RdRp (Fig. 6A) and C. annuum peppers (including Chile blanco) (Fig. 6B) phylogenies are shown by connecting viruses to their host; in many samples, congruence is observed and the admixture is likely related to cross-pollination between different peppers that can lead to viral transmission.

CFEV 1 was detected in four Capsicum species, but in none of our $C$. annuum peppers. Ecu was the only $C$. pubsecens positive for this virus; however, it could have been due to our small collection (eight samples) from this species. While our SNP markers did not resolve non-annuum phylogenies to verify the species identification for this pepper, the possibility of misclassification of this pepper is low, since morphological traits of C. pubescens and C. baccatum are quite distinct (Jarret 2008).

\section{A}

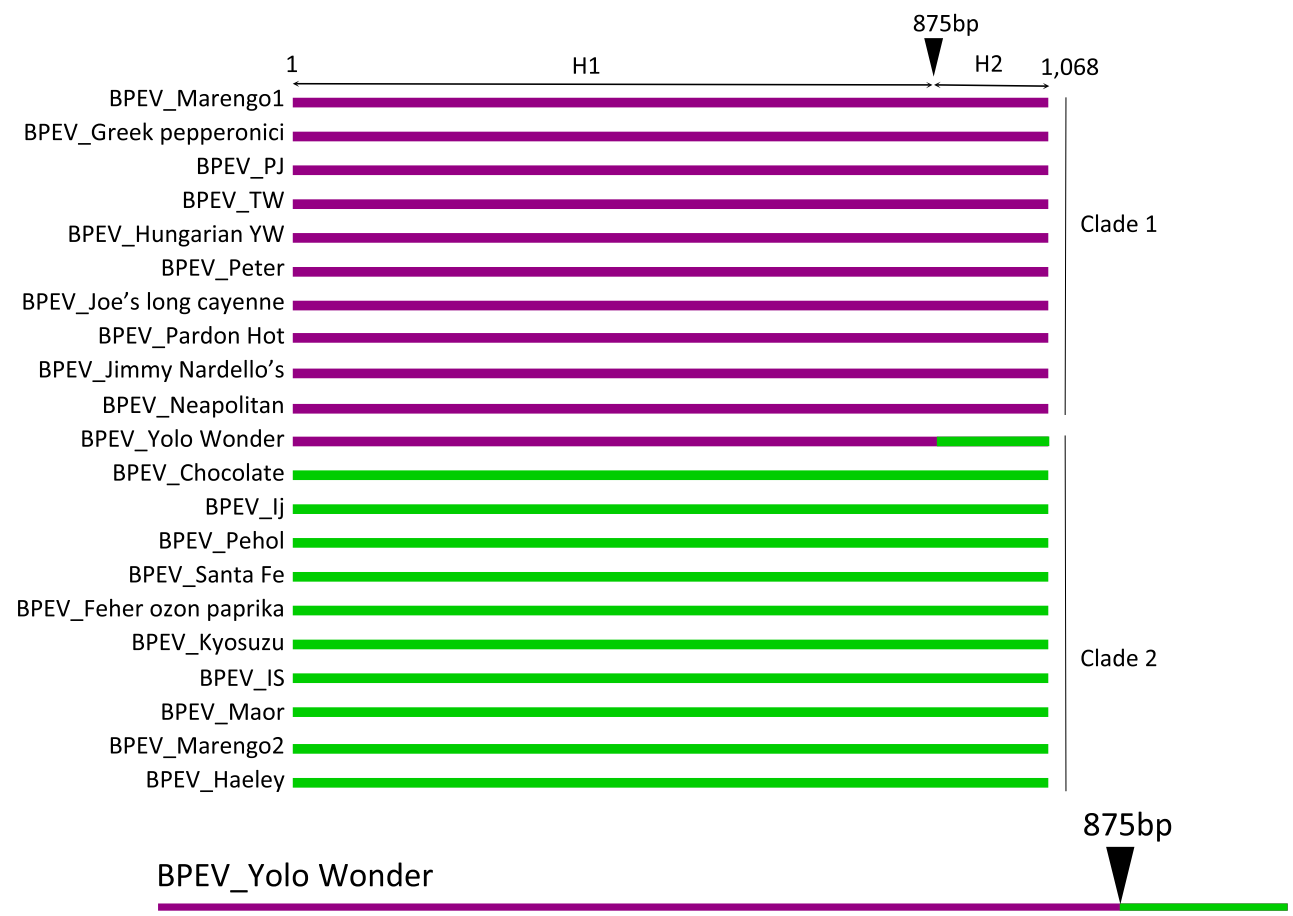

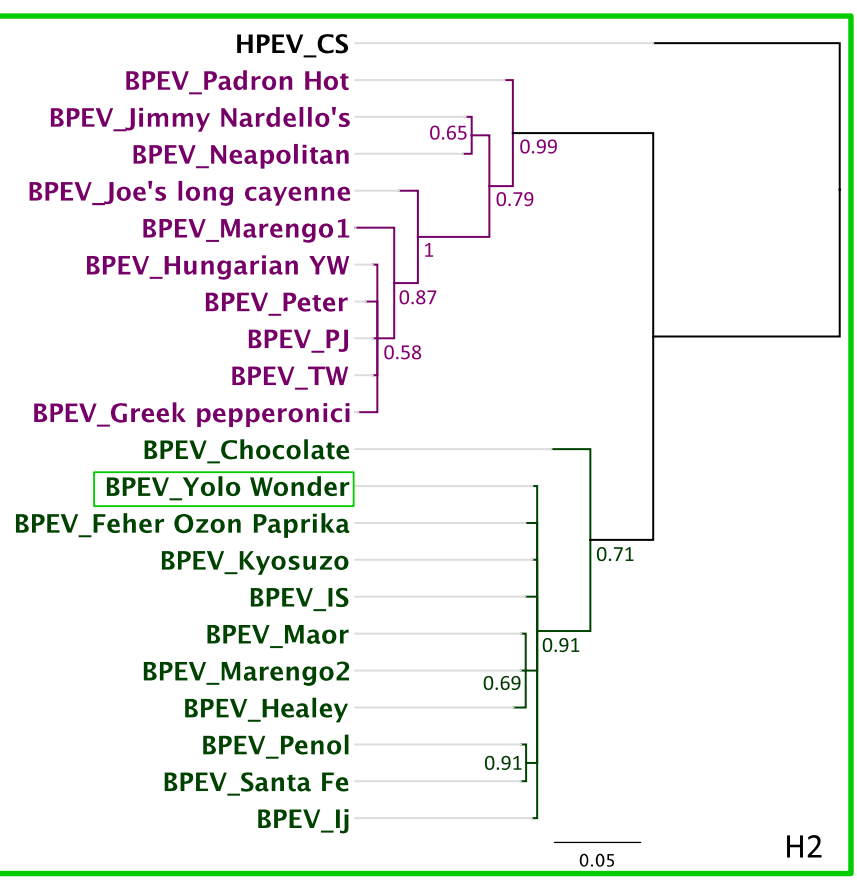

Fig. 5. Recombination in the BPEV_Hel fragment. A, Schematic nucleotide sequence alignment display of the BPEV Hel fragment, color is based on the similarity of the sequences. Purple corresponds to the first $875 \mathrm{nt}$ of the BPEV_Hel, and green represents the rest of the sequence (approximately $200 \mathrm{bp}$ ). B, Bayesian analysis of the relationships among aligned nucleotide sequences of the BPEV_Hel fragment isolated from different peppers for the H1 and $\mathrm{H} 2$ alignments. Trees were generated by MrBayes in Geneious 10.0.9, using the best fit model (HKY + I). Posterior probabilities are shown on the nodes. Hot pepper endornavirus (HPEV) was used as an outgroup. 
Hybrids of $C$. pubsecens with the other four Capsicum spp. are sterile, so there is no chance for the virus to be transmitted by cross-pollination. Hence, this is evidence for the presence of an endornavirus in the ancestor of all of these Capsicum species.

Most of the screened $C$. baccatum peppers were positive for CFEV 1. CFEV 1 isolates from 470 and No 1553 peppers (C. baccatum var. baccatum), the wild form of this species (Nimmakayala et al. 2016), are grouped together in the BCP clade (Fig. 3), separate from the other isolates. The high incidence of CFEV 1 in C. baccatum and its detection in the wild subspecies implies that $C$. baccatum is the original host of CFEV 1. During Capsicum speciation, breeding, and dispersal this virus could have been transmitted to $C$. frutescens and $C$. chinense. The interspecific compatibility between these three species also supports this hypothesis (Walsh and Hoot 2001). The locations of $C$. baccatum peppers infected with CFEV 1 were mainly from South America (Peru, Bolivia, Ecuador, Paraguay, Brazil, and Argentina), which is congruent with origin and speciation of Capsicum spp. During pepper speciation, the ancestor of CFEV 1 may have evolved as a new endornavirus, BPEV, in C. annuum peppers.

Different approaches such as expressed sequence tag-simple sequence repeat (SSR), isozyme, plastid DNA, and SNP analysis confirmed that $C$. chinense and $C$. frutescens were closely related to $C$. annuum, with $C$. baccatum more distant (Jarret 2008; Shirasawa et al. 2013; Walsh and Hoot 2001). It is interesting that we did not detect any BPEV in non-annuum capsicum, while CFEV 1 was found in $C$. chinense and C. frutescens and C. baccatum. It can be concluded that the ancestor of these Capsicum species was infected by an endornavirus, and during speciation and domestication of peppers, the virus was transmitted and diverged in different peppers.

\section{MATERIALS AND METHODS}

\section{Pepper collection.}

We collected 97 different peppers, including C. апnиum, C. chinense, C. frutescens, C. baccutum, C. pubescens, and C. chacoense, with different improvement levels (cultivars, landraces, or wild materials). The seed sources and information are found in Supplementary Table S2. Seeds were germinated in wet paper towels and were then transferred to plastic pots containing Sun-Gro Horticulture soil and were grown in an insect-free environmental room at $24^{\circ} \mathrm{C}$ with fluorescent light (16-h-light and 8-h-dark photoperiod).

\section{Screening Capsicum spp. for the presence of BPEV and CFEV 1.}

To screen plants for the presence of endornaviruses, dsRNAs were extracted from $5 \mathrm{~g}$ of fresh weight leaves, using the protocol described previously (Márquez et al. 2007).

For BPEV, based on the available sequences in GeneBank, primer pairs specific to part of the RdRp (BPEV_RdRp) and Hel (BPEV_Hel) domains were designed to amplify 1,240and 1,162-bp fragments, respectively. Based on sequence information for CFEV 1 (provided by R. Valverde, Louisiana State University), specific primers for part of the RdRp (CFEV 1_RdRp) and Hel (CFEV 1_Hel) domains were designed to amplify 1,101 and 1,016 bp, respectively. For the RT reaction, we used about $2 \mu \mathrm{g}$ of dsRNA, mixed with $2 \mu \mathrm{M}$ reverse primer, $0.5 \mathrm{mM}$ of Tris-EDTA ( $\mathrm{pH} \mathrm{8.0)}$ ), and nuclease-free water to a final volume of $12 \mu \mathrm{l}$ and boiled for $2 \mathrm{~min}$. The mixture was incubated on ice for $2 \mathrm{~min}$ and $8 \mu \mathrm{l}$ of RT mix (200 U of MMuLV reverse transcription [New England Biolabs], $2 \mu \mathrm{l}$ of $10 \times$ M-MuLV buffer [supplied by the manufacturer] and $10 \mathrm{mM}$ dNTPs) was added and incubation was continued at $42^{\circ} \mathrm{C}$ for $1 \mathrm{~h}$. Then, cDNA was incubated with $10 \mu \mathrm{g}$ of boiled RNase A (Sigma) for $15 \mathrm{~min}$ at room temperature and was cleaned with E.Z.N.A cycle pure kit (Omega Bio-Tech) according to the manufacture's instruction. About $0.5 \mu \mathrm{g}$ of cleaned cDNA was used as a template for a $25 \mu \mathrm{l}$ PCR with Taq DNA polymerase (ThermoFisher Scientific), buffer (30 $\mathrm{mM} \mathrm{MgCl}_{2}$, Idaho Technologies), $2 \mathrm{mM}$ dNTPs, and $0.2 \mu \mathrm{M}$ forward and reverse primers for each fragment. The PCR reactions were completed in capillary tubes with an Idaho Technologies rapid cycler for 40 cycles $\left(94^{\circ} \mathrm{C}\right.$ denaturation for $0 \mathrm{~s}, 48^{\circ} \mathrm{C}$ annealing for $0 \mathrm{~s}$, and $72^{\circ} \mathrm{C}$ extension for $45 \mathrm{~s}$ ). The RT-PCR products were separated on a $1.2 \%$ agarose gel in $0.5 \times$ Tris-borate-EDTA, and

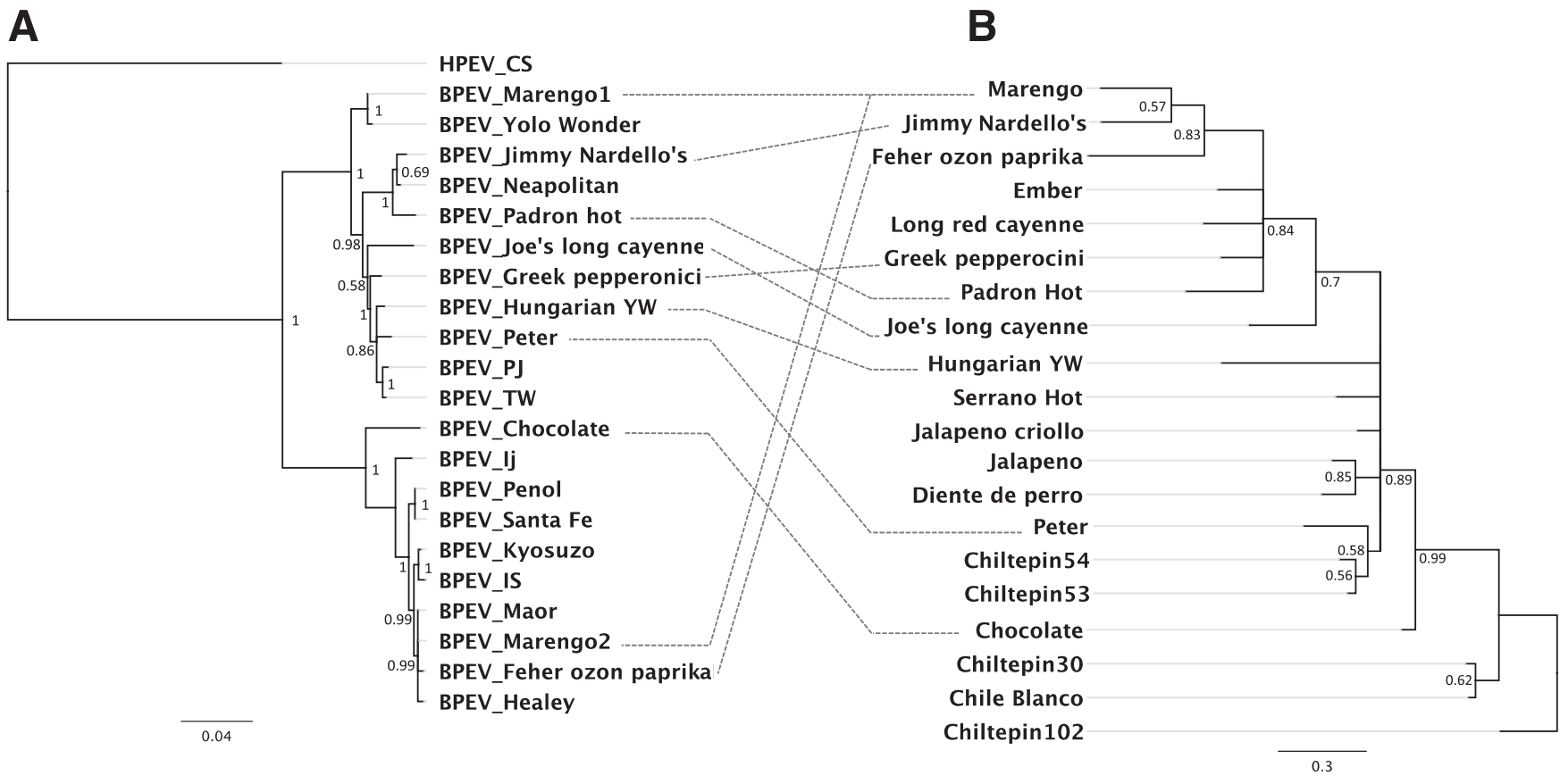

Fig. 6. Congruence between the A, BPEV_RdRp and B, pepper phylogenies. For pepper, Capsicum annuum samples and Chile banco were included and Chiltepin 102 was used as an outgroup. The tree was generated by MrBayes in Geneious 10.0.9, using GTR + I. Posterior probabilities are shown on nodes. 
appropriate bands were excised and purified using E.Z.N.A. gel extraction kit (Omega Bio-Tech). Sequence analysis of the PCR products was done by the Genomic Core Facility of Pennsylvania State University, University Park, PA, U.S.A. The sequences have been deposited in GenBank under the accession numbers listed in Supplementary Table S4.

Nucleotide sequences were aligned with Clustal W using default settings in the program Geneious 10.0.9 (Kearse et al. 2012). The alignment was visually corrected as necessary. Phylogenetic analysis was performed using MrBayes (Ronquist and Huelsenbeck 2003) implemented as a Geneious plug-in. The nucleotide sequences of 12 full-length sequences of BPEV available in GenBank were included in the phylogenetic analysis. HPEV was used as an outgroup for the phylogenies of BPEV regions. For the phylogenies of all pepper endornaviruses Phaseolus vulgaris endornavirus 2 was used as an outgroup. For BPEV_RdRp and BPEV_Hel phylogenies, the HKY $98+$ I substitution model and, for Endornaviridae_RdRp and _Hel phylogenies, GTR + G + I were selected as the best fit models, according to JModelTest (Darriba et al. 2012); burn-in and chain length were 100,000 and 1,100,000, respectively.

\section{Deep sequencing of the Marengo isolate of BPEV.}

The dsRNA extracted from Marengo bell pepper was treated with RQ1 DNase (Promega) and, after cDNA preparation as described above using tagged primers for multiplexing, was sequenced as part of a pool of 96 samples at the Oklahoma
Medical Research Foundation, Clinical Genomic Center, using the Illumina HiSeq 3000 system. The raw data were trimmed using trimmomatic and quality was assessed by fastqc. Reads were assembled using the Velvet (1.2.10) program and were mapped against the BPEV Yolo Wonder isolate (JN019858.1) as a reference sequence. The consensus sequence was used for the analysis.

\section{Pepper phylogenies and population structure.}

To determine the phylogeny of peppers, DNA of plants listed in Table 3 was extracted, using cetyltrimethylammonium bromide (CTAB) as described previously (Healey et al. 2014), with some modifications. Plant tissue $(0.5 \mathrm{~g})$ was flash-frozen in liquid nitrogen, was ground to a fine powder, and was mixed with $5 \mathrm{ml}$ of preheated extraction buffer $(100 \mathrm{mM}$ Tris- $\mathrm{HCl}, \mathrm{pH}$ 7.5, $25 \mathrm{mM}$ EDTA, $1.5 \mathrm{M} \mathrm{NaCl}, 2 \%$ [wt/vol] CTAB, and $0.3 \%$ [vol/vol] $\beta$-mercaptoethanol). The sample was incubated at $65^{\circ} \mathrm{C}$ and was mixed by inversion every $10 \mathrm{~min}$ for $30 \mathrm{~min}$, followed by centrifugation for $5 \mathrm{~min}$ at $5,000 \times g$. The supernatant was transferred to a fresh tube and was mixed with an equal volume of phenol/chloroform ( $1: 1, \mathrm{wt} / \mathrm{wt})$. After mixing by inversion for $5 \mathrm{~min}$, the sample was centrifuged for $10 \mathrm{~min}$ at $5000 \times g$ and the upper phase was transferred to a new tube and was treated with $5 \mu \mathrm{l}$ of RNAse A $(10 \mathrm{mg} / \mathrm{ml})$ (Sigma-Aldrich) for $15 \mathrm{~min}$ at $37^{\circ} \mathrm{C}$, followed by an additional extraction as above with phenol/chloroform. The final aqueous phase was precipitated with $0.3 \mathrm{M}$ sodium acetate and two volumes of

Table 3. Peppers used for Kompetitive Allele-Specific PCR (KASP) analysis

\begin{tabular}{|c|c|c|c|}
\hline Line name $^{\mathbf{a}}$ & Species & Location $^{b}$ & $\mathbf{P I}^{\mathbf{c}}$ \\
\hline Marengo & Capsicum annиum var. anпиит & United States & - \\
\hline Jalapeno & C. аппиит var. аппиит & United States & - \\
\hline Serrano Hot & C. аппиит var. аппиит & United States & \\
\hline Long Red Cayenne & C. апnиит var. anпиит & United States & \\
\hline Jalapeno Criollo & C. аппиит var. аппиит & Guatemala & PI 666462 \\
\hline Jimmy Nardello’s & C. аппиит var. аппиит & United States & - \\
\hline Feher Ozon Paprika & C. аппиит var. anпиит & United States & - \\
\hline Joe's Long Cayenne & C. аппиит var. аппиит & United States & - \\
\hline Greek Pepperoncini & C. апnиит var. anпиит & United States & - \\
\hline Hungarian YW & C. аппиит var. аппиит & United States & - \\
\hline Padron Hot & C. аппиит var. anпиит & United States & _- \\
\hline Peter & C. аппиит var. аппиит & United States & - \\
\hline Chocolate & C. аппиит var. аппиит & Guatemala & PI 666471 \\
\hline Ember & C. annuит var. anпиum & United States & PI 273426 \\
\hline Chiltepin30 & C. аппиит var. glabriusculum & Guatemala & PI 632932 \\
\hline Chiltepin53 & C. annuum var. glabriusculum & Mexico & \\
\hline Chiltepin54 & C. апnиит var. glabriusculum & Mexico & \\
\hline Chiltepin102 & C. annuum var. glabriusculum & Mexico & \\
\hline Habanero Red & C. chinense & United States & - \\
\hline Chile Blanco & C. chinense & Mexico & PI 574545 \\
\hline 30040 & C. chinense & United States & PI 159236 \\
\hline Royal Gold & C. chinense & Peru & PI 315023 \\
\hline Lemon Drop & C. chinense & Peru & PI 315024 \\
\hline Aribibi Gusano & C. frutescens & Bolivia & PI 573337 \\
\hline Greenleaf Tabasco Al & C. frutescens & United States & PI 634826 \\
\hline Tabasco L-167 & C. frutescens & United States & PI 640909 \\
\hline $\mathrm{Ecu}$ & C. pubescens & Ecuador & PI 585262 \\
\hline Lemon Drop Hot & C. baccatum & United States & - \\
\hline WWMC 126 & C. baccatum var. pendulum & Paraguay & PI 632927 \\
\hline WW141 & C. baccatum var. pendulum & Paraguay & PI 633756 \\
\hline MC145 & C. baccatum var. pendulum & Paraguay & PI 633757 \\
\hline Malagueta & C. baccatum var. pendulum & Brazil & PI 260543 \\
\hline Valentine & C. baccatum var. pendulum & Peru & PI 260549 \\
\hline Omnicolor & C. baccatum var. pendulum & Peru & PI 260590 \\
\hline BGH 4215 & C. baccatum var. pendulum & Brazil & PI 441589 \\
\hline 470 & C. baccatum var. baccatum & Peru & PI 215699 \\
\hline No 1553 & C. baccatum var. baccatum & Bolivia & PI 238061 \\
\hline
\end{tabular}

\footnotetext{
${ }^{a}$ Cultivar name or other reference name.

${ }^{\mathrm{b}}$ Location of the seed source.

${ }^{\mathrm{c}}$ Plant Introduction number.
} 
absolute ethanol. The pellet was washed with $70 \%$ ethanol, was dried, and was resuspended in $100 \mu \mathrm{l}$ of Tris-EDTA buffer. DNA samples were sent to TraitGenetics Company in Germany for a KASP assay with 96 SNPs. The KASP genotyping assay is a fluorescence-based reporting system for detection of the alleles (SNPs) at a specific locus within the genomic DNA (Ashrafi et al. 2012; He et al. 2014). The SNP information is provided in Supplementary Table S5.

SNPs within different pepper lines identified in the KASP analysis were used for a Bayesian cluster estimation of population structure, using the STRUCTURE software (version 2.3.4) (Pritchard et al. 2000). STRUCTURE was run for $K=1$ to $K=10$ ( $K=$ number of clusters), and for each $K$ value, 10 replicates were performed with a burn-in of 35,000 followed by 30,000 Markov chain Monte Carlo iterations after burn-in. The replicate with highest probability of $K$ was selected. In addition, to reveal the phylogenetic origin of these pepper lines, a phylogenetic tree was generated with the SNP data, using MrBayes in Geneious. JModelTest suggested a Sym substitution model, but since it is not implemented in MrBayes, several models were tested that all resulted in the same tree, and the GTR + I substitution model was selected as the best fit model; burn-in was 100,000 and total chain length was $1,100,000$.

\section{ACKNOWLEDGMENTS}

We thank R. Valverde for providing the CFEV 1 RdRp and Hel sequences. We appreciate all the people who helped us to collect different peppers, F. García-Arenal (providing chiltepins samples), M. D. Orzolek, R. BelloBedoy, A. Stephenson, USDA-GRIN (most of the samples). Special thanks to R. Jarret for his guidance in pepper information, H. Ashrafi and T. Hill for their discussions about pepper markers and analysis.

\section{LITERATURE CITED}

Ashrafi, H., Hill, T., Stoffel, K., Kozik, A., Yao, J., Chin-Wo, S. R., and Van Deynze, A. 2012. De novo assembly of the pepper transcriptome (Capsicum annuum): A benchmark for in silico discovery of SNPs, SSRs and candidate genes. BMC Genomics 13:571.

Carrizo García, C., Barfuss, M. H. J., Sehr, E. M., Barboza, G. E., Samuel, R., Moscone, E. A., and Ehrendorfer, F. 2016. Phylogenetic relationships, diversification and expansion of chili peppers (Capsicum, Solanaceae). Ann. Bot. 118:35-51.

Carrizo García, C. C., Sterpetti, M., Volpi, P., Ummarino, M., and Saccardo, F. 2013. Wild capsicums: Identification and in situ analysis of Brazilian species. Pages 205-213 in: Breakthroughs in the Genetics and Breeding of Capsicum and Eggplant. Proceedings of the XV EUCARPIA Meeting on Genetics and Breeding of Capsicum and Eggplant, September 2 to 4 , 2013. S. Lanteri and G. L. Rotino, eds. Comitato per l'organizzazione degli evenit (COE) DISAFA, Torino, Italy.

Coutts, R. H. A. 2005. First report of an endornavirus in the Cucurbitaceae. Virus Genes 31:361-362.

Darriba, D., Taboada, G. L., Doallo, R., and Posada, D. 2012. jModelTest 2: More models, new heuristics and parallel computing. Nat. Methods 9,772.

Debat, H. J., Grabiele, M., Aguilera, P. M., Bubillo, R., Zapata, P. D., Marti, D. A., and Ducasse, D. A. 2014. The complete genome of a putative endornavirus identified in yerba mate (Ilex paraguariensis St. Hil.). Virus Genes 49:348-350.

Eshbaugh, W. H. 1993. Peppers, History and Exploitation of a Serendipitous New Crop Discovery. Pages 132-139 in: New Crops, J. Janick and J. E. Simon, eds. Wiley, New York.

Espach, Y., Maree, H. J., and Burger, J. T. 2012. Complete genome of a novel endornavirus assembled from next-generation sequence data. J. Virol. 86:13142.

Fukuhara, T., and Moriyama, H. 2008. Endornaviruses. Pages 109-116 in: Encyclopedia of Virology, B. W. J. Mahy and M. H. V. vanRegenmortel, eds. Elsevier, Oxford.

González-Jara, P., Moreno-Letelier, A., Fraile, A., Piñero, D., and GarcíaArenal, F. 2011. Impact of human management on the genetic variation of wild pepper: Capsicum annuum var. glabriusculum. PLoS One 6:e28715.

Gutiérrez, P. A., Marín-Montoya, M., and Muñoz-Baena, L. 2017. Genome sequencing of two Bell pepper endornavirus (BPEV) variants infecting Capsicum annuum in Colombia. Agronomía Colombiana 35:44-52.
He, C., Holme, J., and Anthony, J. 2014. SNP Genotyping, The KASP Assay. Pages 75-86 in: Crop Breeding, Methods and Protocols. Fleury, D., and Whitford, R., eds. Springer, New York.

Healey, A., Furtado, A., Cooper, T., and Henry, R. J. 2014. Protocol, a simple method for extracting next-generation sequencing quality genomic DNA from recalcitrant plant species. Plant Methods 10:21.

Hill, T. A., Ashrafi, H., Reyes-Chin-Wo, S., Yao, J., Stoffel, K., Truco, M.-J., Kozik, A., Michelmore, R. W., and Van Deynze, A. 2013. Characterization of Capsicum annuum genetic diversity and population structure based on parallel polymorphism discovery with a $30 \mathrm{~K}$ unigene Pepper GeneChip. PLoS One 8:e56200.

Horiuchi, H., Moriyama, H., and Fukuhara, T. 2003. Inheritance of Oryza sativa endornavirus in F1 and F2 hybrids between japonica and indica rice. Genes Genet. Syst. 78:229-234.

Hulse-Kemp, A. M., Ashrafi, H., Plieske, J., Lemm, J., Stoffel, K., Hill, T., Luerssen, H., Pethiyagoda, C. L., Lawley, C. T., Ganal, M. W., and Van Deynze, A. 2016. A HapMap leads to a Capsicum annuum SNP infinium array: A new tool for pepper breeding. Hortic. Res. 3:16036.

Jarret, R. L. 2008. DNA barcoding in a crop genebank, the Capsicum аппиит species complex. Open Biol. J. 1:35-42.

Jo, Y., Choi, H., Kim, S.-M., Kim, S.-L., Lee, B. C., and Cho, W. K. 2017. The pepper virome, natural co-infection of diverse viruses and their quasispecies. BMC Genomics 18:453.

Jo, Y., Choi, H., Yoon, J.-Y., Choi, S.-K., and Cho, W. K. 2016. In silico identification of Bell pepper endornavirus from pepper transcriptomes and their phylogenetic and recombination analyses. Gene 575:712-717.

Kearse, M., Moir, R., Wilson, A., Stones-Havas, S., Cheung, M., Sturrock, S., Buxton, S., Cooper, A., Markowitz, S., Duran, C., Thierer, T., Ashton, B., Mentjies, P., and Drummond, A. 2012. Geneious Basic: An integrated and extendable desktop software platform for the organization and analysis of sequence data. Bioinformatics 28:1647-1649.

Kraft, K.H., Brown, C.H., Nabhan, G.P., Luedeling, E., Ruiz, J.d.J.L., d'Eeckenbrugge, G.C., Hijmans, R.J., and Gepts, P. 2014. Multiple lines of evidence for the origin of domesticated chili pepper, Capsicum annuum, in Mexico. Proc. Natl. Acad. Sci. U.S.A. 111:6165-6170.

Lim, S., Kim, K. H., Zhao, F., Yoo, R. H., Igori, D., Lee, S.-H., and Moon, J. S. 2015. Complete genome sequence of a novel endornavirus isolated from hot pepper. Arch. Virol. 160:3153-3156.

Márquez, L. M., Redman, R. S., Rodriguez, R. J., and Roossinck, M. J. 2007. A virus in a fungus in a plant-Three-way symbiosis required for thermal tolerance. Science 315:513-515.

Molina, J., Sikora, M., Garud, N., Flowers, J. M., Rubinstein, S., Reynolds, A., Huang, P., Jackson, S., Schaal, B. A., Bustamante, C. D., Boyko, A. R., and Purugganan, M. D. 2011. Molecular evidence for a single evolutionary origin of domesticated rice. Proc. Natl. Acad. Sci. U.S.:A. 108:8351-8356.

Moriyama, H., Nitta, T., and Fukuhara, T. 1995. Double-stranded RNA in rice: A novel RNA replicon in plants. Mol. Gen. Genet. 248:364-369.

Nakatsukasa-Akune, M., Yamashita, K., Shimoda, Y., Uchiumi, T., Abe, M., Aoki, T., Kamizawa, A., Ayabe, S., Higashi, S., and Suzuki, A. 2005. Suppression of root nodule formation by artificial expression of the TrEnodDR1 (coat protein of White clover cryptic virus 1) gene in Lotus japonicus. Mol. Plant-Microbe Interact. 18:1069-1080.

Nicolai, M., Cantet, M., Lefebvre, V., Sage-Palloix, A.-M., and Palloix, A. 2013. Genotyping a large collection of pepper (Capsicum spp.) with SSR loci brings new evidence for the wild origin of cultivated $C$. annuum and the structuring of genetic diversity by human selection of cultivar types. Genet. Resour. Crop Evol. 60:2375-2390.

Nimmakayala, P., Abburi, V. L., Saminathan, T., Almeida, A., Davenport, B., Davidson, J., Reddy, C. V. C. M., Hankins, G., Ebert, A., Choi, D. Stommel, J., and Reddy, U. K. 2016. Genome-wide divergence and linkage disequilibrium analyses for Capsicum baccatum revealed by genome-anchored single nucleotide polymorphisms. Front. Plant Sci. 7:1646.

Okada, R., Kiyota, E., Moriyama, H., Toshiyuki, F., and Valverde, R. A. 2014. A new endornavirus species infecting Malabar spinach (Basella alba L.). Arch. Virol. 159:807-809.

Okada, R., Kiyota, E., Sabanadzovic, S., Moriyama, H., Fukuhara, T., Saha, P., Roossinck, M. J., Severin, A., and Valverde, R. A. 2011. Bell pepper endornavirus, molecular and biological properties, and occurrence in the genus Capsicum. J. Gen. Virol. 92:2664-2673.

Pagán, I., and Holmes, E. C. 2010. Long-term evolution of the Luteoviridae: Time scale and mode of virus speciation. J. Virol. 84:6177-6187.

Pfeiffer, P. 1998. Nucleotide sequence, genetic organization and expression strategy of the double-stranded RNA associated with the '447' cytoplasmic male sterility trait in Vicia faba. J. Gen. Virol. 79:2349-2358.

Pickersgill, B. 1997. Genetic resources and breeding of Capsicum spp. Euphytica 96:129-133. 
Pritchard, J. K., Stephens, M., and Donnelly, P. 2000. Inference of population structure using multilocus genotype data. Genetics 155:945-959.

Qin, C., Yu, C., Shen, Y., Fang, X., Chen, L., Min, J., Cheng, J., Zhao, S., Du, M., Luo, Y., Yang, Y., Wu, Z., Mao, 1., Wu, H., Ling-Hu, C., Zhou, H., Lin, H., Morales, S.G., Trejo-Saavedra, D.L., Tian, H., Tang, X., Zhao, M., Huang, Z., Zhou, A., Yao, S., Cui, J., Li, W., Chen, Z., Feng, Y., Niu, Y., Bi, S., Yang, X., Li, W., Cai, H., Luo, X., Montes-Hernández, S., LeyvaGonzález, M.A., Xiong, Z., He, X., Bai, L., Tan, S., Tang, X., Liu, D., Liu, J., Zhang, S., Chen, M., Zhang, L., Zhang, L., Zhang, Y., Liao, W., Zhang, Y., Wang, M., Lv, X., Wen, B., Liu, H., Luan, H., Zhang, Y., Yang, S., Want, X., Xu, J., Li, X., Li, S., Want, J., Palloix, A., Bosland, P.W., Li, Y., Krogh, A., Rivera-Bustamante, R.F., Herrera-Estrella, L., Yin, Y., Yu, J., Hu, K., and Zhang, Z. 2014. Whole-genome sequencing of cultivated and wild peppers provides insights in Capsicum domestication and specialization. Proc. Natl. Acad. Sci. U.S.A. 111:5135-5140.

Ronquist, F., and Huelsenbeck, J. P. 2003. MrBayes 3, Bayesian phylogenetic inference under mixed models. Bioinformatics 19:1572-1574.

Roossinck, M. J. 1997. Mechanisms of plant virus evolution. Annu. Rev. Phytopathol. 35:191-209.

Roossinck, M. J. 2010. Lifestyles of plant viruses. Philos. Trans. R. Soc. Lond. B Biol. Sci. 365:1899-1905.

Roossinck, M. J. 2012. Plant virus metagenomics, biodiversity and ecology. Annu. Rev. Genet. 46:359-369.

Roossinck, M. J. 2015. Metagenomics of plant and fungal viruses reveals an abundance of persistent lifestyles. Front. Microbiol. 5:767.

Roossinck, M. J., and Ali, A. 2007. Mechanisms of plant virus evolution and identification of genetic bottlenecks, Impact on disease management. Pages 109-124 in: Biotechnology and Plant Disease Management, Z. K. Punja, S. H. DeBoer, and H. Sanfaçon, eds. CABI, Wallingford, U.K.
Roossinck, M. J., Sabanadzovic, S., Okada, R., and Valverde, R. A. 2011. The remarkable evolutionary history of endornaviruses. J. Gen. Virol. 92:2674-2678.

Shirasawa, K., Ishii, K., Kim, C., Ban, T., Suzuki, M., Ito, T., Muranaka, T., Kobayashi, M., Nagata, N., Isobe, S., and Tabata, S. 2013. Development of Capsicum EST-SSR markers for species identification and in silico mapping onto the tomato genome sequence. Mol. Breed. 31:101-110.

Valverde, R. A., and Gutierrez, D. L. 2007. Transmission of a dsRNA in bell pepper and evidence that it consists of the genome of an endornavirus. Virus Genes 35:399-403.

Valverde, R. A., and Gutierrez, D. L. 2008. Molecular and biological properties of a putative partitivirus from jalapeño pepper (Capsicum annuum L.). Rev. Mex. Fitopatol. 26:1-6.

Valverde, R. A., Nameth, S., Abdallha, O., Al-Musa, O., Desjardins, P., and Dodds, A. 1990. Indigenous double-stranded RNA from pepper (Capsicum annuum). Plant Sci. 67:195-201.

Villanueva, F., Sabanadzovic, S., Valverde, R. A., and Navas-Castillo, J. 2012. Complete genome sequence of a double-stranded RNA virus from avocado. J. Virol. 86:1282-1283.

Wakarchuk, D. A., and Hamilton, R. I. 1990. Partial nucleotide sequence from enigmatic dsRNAs in Phaseolus vulgaris. Plant Mol. Biol. 14:637-639.

Walsh, B. M., and Hoot, S. B. 2001. Phylogenetic relationships of Capsicum (Solanaceae) using DNA sequences from two noncoding regions, the chlrorplast $a t p B-r b c L$ spacer region and nuclear waxy introns. Int. J. Plant Sci. 162:1409-1418.

Zabalgogeazcoa, I. A., and Gildow, F. E. 1992. Double-stranded ribonucleic acid in 'Barsoy' barley. Plant Sci. 83:187-194. 